\title{
Contextual Factors, Bilingualism and English Language Learning among a Group of Primary School Pupils in Nigeria
}

\author{
Nkechi M. Christopher
}

University of Ibadan, Nigeria

\section{Introduction}

Contextual factors are crucial in second language learning and could constitute a factor in developing motivation to learn and attitudes towards the target language (Gardner, 1991; Hamers\& Blanc, 2000; Erlenawati, 2005). Children's sociolinguistic environment also plays an important role in language use, educational achievement and, eventually, life achievement in Nigeria's ESL (English as a second language) situation. The home and school are the two most important environments in the language learning experience of a Nigerian primary school child, particularly the learning of the English language. The extent to which each environment impacts on the acquisition of English-proficiency could depend on the extent the home supports the school's effort. Homes that do not use English in everyday conversation but support English literacy activities encourage learners in their path to acquiring competence in the language. Generally, oracy characterises the home environment while literacy skills are largely acquired in school, since home literacy habits are just being acculturated.

A major factor in language learning and maintenance in Nigeria is the attitude that could be developed towards languages due to their perceived relevance in children's lives. English is the official language and, despite policy provisions, Nigerian languages are rarely used in high domain areas such as legislative business, and this happens even in monolingual states where Yoruba, Igbo or Hausa are spoken. Local languages are quickly losing their place in society in favour of the English language, which is used in all domains significant to an individual's personal and sociocultural advancement. Therefore, the developing trend in many urban families is the valorisation of English over local languages. Parents speak English to their children, some exclusively, believing that allowing children to learn a local language could be detrimental to learning English. On the other hand, it is sometimes difficult to maintain the native language in city 
"migrant" families, especially where socio-economic situations do not promote clannish interactions among people of similar ethnic backgrounds, or visits to places of origin.

This article examines the interaction between environmental factors, bilingualism/ bilinguality, language use and language learning. A proper understanding of the language learning environment can reveal the state of, and changes in, contextual factors that can or should be taken into consideration in language teaching. Using evidence from an empirical study, I discuss the language situation of the children studied, their language choice and that of their interlocutors, the relationship between bilingual status and academic achievement, multimedia available to children at home and school, and how multimedia access can be exploited for a more engaging English language learning experience.

The study was carried out in Nigeria where English is a second language and the official/national language. A questionnaire was administered to 67 primaries 4 and 6 pupils of the staff school of Nigeria's premier university (University of Ibadan) towards the end of the 2007/2008 session. The children were 7-13-year-old boys and girls from different ethnic/language backgrounds, with Yoruba for the majority (70\%). Teaching is carried out in the second language, but Yoruba is extensively spoken in learners' neighbourhoods and, to some extent, at school.

\section{Contextual factors in learners' environment}

To understand the learners' context of English language learning one needs to examine it right from the perspective of the national through to the immediate community's language situation and the characteristics of the physical environment where the school is located in the university campus. Although Nigeria policy on education recommends that children be taught in the language of the environment in lower primary while learning English as a subject, it is not so with the pupils in this study. Considering that the university hosts families from different ethnic/linguistic backgrounds, the national language, English, is the language of education from a child's first day in school.

\subsection{Language situation}

The English language is not merely a colonial heritage, but also Nigeria's national and official language. Thus, it has become the language of status and socioeconomic mobility in Nigeria. Those who speak English are perceived as learned and vice versa; Nigerians want to be seen as learned or urbane. More 
important, attaining proficiency in the English language is imperative for those who want to advance educationally, since they must pass the English subject, and use it as the medium for learning other subjects. Beyond schooling, employers are raising educational requirements for limited job opportunities. Informal and apprenticeship education that hitherto could use local languages is quickly losing its significance in Nigerian societies after major economic crises stifled small and medium industries. The demand for English is high but the deliverables are insufficient.

Going by Nigeria's bilingual policy, a product of primary education should be bilingual in a Nigerian language and English. This policy is not always practicable for many reasons, one of which is the multiplicity of tongues, since Nigeria has about 450 languages. The local language situation in each state, city or town often impacts on and determines how much English is spoken in any given community where there is a dominant local language, English or Pidgin English is spoken less often. Thus, in capitals of states with much linguistic diversity such as Benin City and Port Harcourt, Pidgin English is the common language, but it has a low status. However, some states in the north, east and west of the country have a common local language, a situation that may resist the dominance of the (Pidgin) English over the prevalent local language. This is the case of the Ibadan community in western Nigeria where this study is located.

The dominance of Yoruba in Ibadan as the language of wider communication may have a limiting effect on how much individuals are eager to acquire proficiency in the English language and indeed on the avenues for doing so. Once a regional capital, Ibadan (the capital of Oyo State) still occupies an important place in the Yoruba speaking area of Nigeria which is made up of six states. In everyday life situations, most listeners may be tuned to hearing one speak in Yoruba more than they would expect to hear English.

Nonetheless, the university environment in which the pupils in this study attend school is somewhat different from the world outside. Because it is a federal university, people are expected to be able to communicate in the English language. This also applies to the staff school which is populated mainly by children of university workers who come from diverse linguistic backgrounds. Against the demands of the national policy of education that mother tongue be used for teaching in the first three years of primary education, English is the language of instruction at the university staff school from the nursery level. 


\subsection{University environment}

The university environment is quite distinct from the world outside its gates. Right from the entrance, the layout and vegetation give it a distinct academic class that tends to socio-psychologically demand the use of English. Characterised by linguistic diversities, more than the larger Ibadan community, the university environment supports the learning and the use of English. English is the common language used by people of different linguistic backgrounds, which make up the community. It is used for all official communication and academic discussions as well as for other facilities within the campus; for example, signs and religious (including Islamic) worships are done in the English language.

\subsection{Staff school environment}

The school attended by pupils studied is a private school established for the education of children of university workers who come from different linguistic backgrounds. Expectedly many of the children would not be fluent in the language of the local community. Established in 1948, when the university was founded, the school is one of the earliest private primary schools in the Ibadan metropolis.

It is situated in an environment with an academic atmosphere in the university compound, close to The Postgraduate School and some academic departments. Pupils pass by the academic facilities on their way to and from the school compound proper; thus, it is easy for them to appreciate that English is the language of the environment.

\section{Bilingualism and bilinguality among subjects}

The Ibadan society may be described as bilingual, but not everybody can speak English. A high level of interaction between English and Yoruba engenders code switching and code-mixing, especially among the sufficiently literate. There is language accommodation between English, pidgin and vernacular. Englishspeaking Yoruba adults often interact in Yoruba, but are often observed speaking to children in the English language, perhaps to encourage the learning of the latter. As in other Nigerian contexts, home literacy in both local languages and English is generally low; more so in case of the former, where less emphasis is laid on its acquisition and the literacy aspect. Literacy in English generally emphasises school-related activities. Unfortunately, modern families are evolving in an era when bookshelves are no longer an essential furnishing item in homes. 
Nonetheless, exceptions to this generalisation may hold where parents are members of the intellectual community.

In spite of its importance in personal advancement, its dominance in formal domains and people's desire to become active users of the language, the English language in Nigeria still largely remains a language learnt in school. Many children that speak fluent English are supported by home (privileged background) and private school education. Thus, proficiency in the English language today in Nigeria is increasingly becoming the privilege of the minority whose parents are educated and can afford the cost of private education for their children. The public education system is only sluggishly recovering from its doldrums. The children in the present study belong to the privileged minority.

In addition to English, Yoruba and French are also taught as subjects in the school under study. While the teaching of Yoruba may improve knowledge of the language, pupils may not learn enough French to be able to communicate in it.

Against this bilingual situational background, we examine the extent of the subjects' bilingualism and bilinguality. According to Hamers and Blanc (2000: 36), "bilinguality is the psychological state of an individual who has access to more than one linguistic code as a means of social communication."All 67 children spoke both English and at least one vernacular language, but the profile of the language they used at home is worthy of note:

- $\quad 5$ or $7.5 \%$ spoke only English

- $\quad 9$ or $13.4 \%$ spoke mainly vernacular (3 did not use English at all)

- $\quad 34$ or $50.7 \%$ spoke English and a local language

- $\quad 19$ or $28.4 \%$ spoke English and two local languages

Essentially, only nine out of the 67 pupils did not speak English at home. Whether this or the extent to which the pupils interacted in English had bearing on class achievement is discussed later.

\subsection{Language of interaction}

The children were asked to indicate what language they spoke to and were spoken to by others:

- at home: father, mother, brother, sister, friends at home, friends' parents, visitors, uncles, aunts and sellers,

- at school: teacher, schoolmates and schoolmates' parents 
The profiling of the language of communication indicates that language choices differed with categories of people. In all profiles of language choices students indicated (or rather perceived) that they were more likely to use English while speaking to others than others did while speaking to them. The difference between language choice by students and that by others is statistically significant. Overall, a hierarchy of language choices emerges as follows:

English > Vernacular > English or/and vernacular.

(Primary 6 pupils were less likely to use English/vernacular option than Primary 4.)

The use of English at school and at home was encouraged. The profiles further reveal the following situation: more teachers than parents, more peers at school than peers at home, and more parents of schoolmates than parents of friends at home were more likely to speak to subjects in English rather than in vernacular or English/vernacular, and vice versa. These findings indicate that person and place, among other factors, influenced the choice of language of the subjects and their interlocutors (Jarovinskij, 1995). We would then expect that children from vernacular-speaking homes should easily catch up with speaking English at school and fit into the school environment.

\subsection{Language attitudes and educational achievement}

Motivation to learn a language can be influenced by social context (Hamers\& Blanc, 2000) and attitude towards language speakers/owners (Zhongganggao, 2002). Motivation and attitude can both influence how well a language is learnt (Gardner, Masgoret and Tremblay, 1999). Although the learners are in no position to have an attitude towards native speakers (since there is little or no contact with native speakers), the sociocultural environment places high value on English proficiency. A context in which the English language is the language of the educated and social mobility is likely to elicit a favourable attitude towards it in Nigeria - a situation that has a positive impact on its learning when well-taught. It is not surprising that all the children in the study indicated that they liked English lessons. However, the extents to which they liked to speak it differ:

Table 1: $\quad$ Extent pupils liked to speak English

Frequency

Sometimes

Often

Always

Total
Number

16

11

38

65
Percent

24.6

16.9

58.5

100.0 
The result in the table indicates that more than half of the subjects liked to speak English all the time. Other results show that it was more the case among Primary 6 (68.4\%) than Primary 4 (44.4\%) pupils, and that $67 \%$ of the pupils spoke English alone to their friends at home.

These results suggest that the subjects were conversant with English and used it extensively. Notwithstanding, class performance in the first and second terms of the session under study does not indicate that the attitude ("like to speak the language") had much impact on performance, as explained below:

- Individual students' scores for the two terms studied are not consistent (that is, it could be high in one term and low in the other), but the difference is not significant.

- There is no relationship between attitude to English and educational achievement in the English subject.

- However, the correlation between attitude to English and average score in all subjects was negative but low for each term and for the two terms combined.

It is evident that class performance at this level is not aligned with attitude to English. On the one hand, it could be that "English as a subject" is different from "English used as a means of communication;" and, on the other hand, the assessment method used may not have included the oral/aural component. Other factors such as intelligence could also have been at play.

The relationship between language spoken at home and achievement was also assessed. The results show that although a pupil that spoke vernacular at home scored the lowest mark in each term, the highest scores were not earned by those that spoke English alone. In fact, the highest average score in that category was placed 11th in a group of 63 , while the 2 nd -5 th highest average scores were earned by those that spoke English and two vernaculars at home. Nonetheless, average scores for the two terms favour those that spoke more of English than not, as shown below:

Vernacular alone (9 pupils)

$58.72 \%$

English + two vernacular (17 pupils)

$68.67 \%$

English + one vernacular (32 pupils)

$69.90 \%$

English only (5)

$74.80 \%$

It may be inappropriate to prescribe an English-alone situation, but these results point to the importance of ensuring that the school compensates for limitations posed by poor sociolinguistic and literacy backgrounds of pupils, especially in public schools where performance has been poor (Christopher, 2008). The home 
background determines the resources pupils have access to, which can create opportunities for language use and development (Wells \& Nicholls, 1985).

\subsection{Opportunities for language use: multimedia activities and use of library}

Effective language learning should extend beyond the classroom and textbook, to include, for example, the use of multimedia tools and library resources. Pupils' responses on how often they were taught with the assistance of computers suggest that information communication technologies (ICT) had not been integrated into teaching:

$\begin{array}{lll}\text { "No" } & = & 34.3 \% \\ \text { "Once a week" } & = & 55.2 \% \\ \text { "More than once a week" } & = & 10.4 \%\end{array}$

Meanwhile, the children indicated that they used digital tools and indulged in all of the 16 multimedia activities listed in the questionnaire administered to them to different extents.

\section{Table 2: $\quad$ Personal Multimedia activities}

\begin{tabular}{|c|c|c|c|}
\hline \multicolumn{4}{|l|}{ TV screen } \\
\hline • & Watch TV & $98.5 \%$ & \\
\hline - & Watch video film & $86.4 \%$ & \\
\hline - & Watch DSTV & $66.2 \%$ & \\
\hline - & Play video games & $73.8 \%$ & \\
\hline \multicolumn{4}{|c|}{ Phones (handset/landphone) } \\
\hline - & Play games in the handset & $81.8 \%$ & \\
\hline - & Read text message & $80.0 \%$ & \\
\hline • & \multicolumn{3}{|c|}{ Make/receive calls on handset $69.2 \%$} \\
\hline - & Send text message & $50.8 \%$ & \\
\hline • & Make use of land phone & $35.9 \%$ & \\
\hline \multicolumn{4}{|c|}{ Computer (and laptop) } \\
\hline - & Read/write with computer & $77.3 \%$ & \\
\hline • & Play with computer & $74.2 \%$ & \\
\hline • & Play computer games & $72.3 \%$ & \\
\hline • & Use laptop & $53.1 \%$ & \\
\hline \multicolumn{4}{|l|}{ Internet use } \\
\hline - & Use Internet & $49.3 \%$ & \\
\hline - & Browse the Internet at home & $42.4 \%$ & \\
\hline - & Browse the Internet at cyberc & afés & $35.5 \%$ \\
\hline Listen to radio & & $73.8 \%$ & \\
\hline
\end{tabular}


Similarly, the use of the school library seems to be lower than pupils' enthusiasm for reading. The larger number of pupils (83\%) said the library was used once a week, but over a half of them (55\%) read story books every day. Only 5\% read story books once a week, while $40 \%$ read only whenever they found one.

If harnessed, pupils' reading habits and multimedia activities can increase language learning and the sociocultural environment can become supportive of English language learning.

\section{Utilising multimedia tools in language teaching}

Many children had access to opportunities for extending the learning and use of English beyond the school in reading/writing and speaking/listening extensions.

Table 3: Personal extension of language skills by pupils

\begin{tabular}{|lc|}
\hline \multicolumn{2}{|l|}{ Pupils' reading/writing extension } \\
\hline Internet use & $49.3 \%$ \\
Read/write with handset & $74.6 \%$ \\
Read/write on computer & $77.3 \%$ \\
Handset \& computer (Ave) & $76.0 \%$ \\
Independent reading & $100 \%$ \\
\hline \multicolumn{2}{|l}{} \\
Pupils' speaking/listening extension \\
Listening to radio & $73.8 \%$ \\
Viewing of TV screen media & $98.5 \%$ \\
Phone calls & $69.2 \%$ \\
\hline
\end{tabular}

Private language skills extensions can be integrated into the learning process to improve class achievement. Exploiting individual multimedia activities and utilising multimodal approach to teaching could increase learners' language learning capacity and proficiencies in the English language and comprehension in content areas. Multimodal teaching can increase learners' experience in English language, engender multiliteracies, equip learners to better deconstruct and construct multimodal texts, and can enhance the use of multimedia facilities (e.g. the Internet) to greater advantage. Multimodal teaching eases the teaching of difficult concepts in content areas by exposing learners to different expressions and experience of concepts.

Multimodal teaching is recommended for literacy teaching for many reasons. Literacy is no longer limited to the ability to read and write. Callow (2008: 616) 
notes that children need multiliteracies to be able to negotiate texts in their environment, which "often use more than one mode, such as the visual and written modes on a cereal box; the audio mode for a podcast; or the audio, visual, written and gestural modes used with interactive multimedia or video games." Moreover, it has become important to teach learners to be more critical consumers of media products such as the Internet (Thompson, 2008).

Again, in a second language situation such as Nigeria where English language proficiency is suboptimal in the larger sociolinguistic environment, the home and the school can be brought together by helping children take what they learn in school (language rules and literacy practice) to their home environments and bring their environments (e.g. multimedia practice) to the classroom, thereby increasing collaborative learning and making school more meaningful and relevant to learners' life. As Weinstein (2006: 280) observes, "young people respond to activities in which they can take an active role and connect to their lived experiences and the cultures of their families and communities." Students have productive learning strategies, the author notes, and these can be brought to the fore in multimodal learning. In such an expanded learning environment, as they use multimodal texts, teachers become aware of learners' strengths that can compensate for observed weaknesses.

Multimodal texts are non-traditional texts "that convey meaning through multiple sign systems such as gestures, spoken words, written words, numeric equations, photographs, diagrams, and so forth" (Wilson, 2008: 154). Also, according to Nokes (2008), they are texts that are not written or read using letters or words in the usual sense such as paintings, photographs, historical artefacts, coins, music, dances and movies. Teachers are to adapt multimedia tools and multimodal texts to their teaching (Nokes, 2008). In this vein, Wilson (2008) shows how to use the multimodal approach in teaching science concepts, and Callow (2008) reveals how to assess multimedia/ multimodal compositions by learners.

Thompson (2008) and LaMonde and Rogers (2007) received favourable responses from teachers who learnt to adapt multimodal teaching. Multimodal/multimedia teaching improves cognitive strategies essential for interacting with texts (Nokes, 2008). It involves the "whole learner" (Savignon, 1987: 237), linking learner's affective, physical and cognitive elements for increased learning (Gardner, 1983). Learners lose inhibitions as they fully engage in learning tasks. Thus, SilverPacuilla (2006) sees it as a means of assisting learners with learning disabilities, especially those that may be difficult to identify in the traditional classroom. 
Further, LaMonde and Rogers (2007) make these observations about multimodal teaching/learning: it is inclusive, supporting diverse learning styles and multiple intelligences; it is engaging, motivating and dynamic; it supports conceptual understanding; it provides new forms of expression and encourages critical perspectives.

\section{Conclusion}

Today's Nigerian child is more linguistically deprived than the children of yesteryear, specifically up to the 1970s, due to changing socioeconomic and cultural environments. The contemporary Nigerian environment is deprived of elements in the traditional settings that groomed renowned Nigerian authors, in which children spent adequate time with their mothers and grandparents in rural communities and learnt sociocultural practices and societal mores. Story-telling greatly enriches a child's linguistic development as well as interaction with elders and peers in the community. Today, children in urban settings are deprived of their (working) mothers' presence as well as interaction with grandparents and other relations, due to poor economic conditions that constrain meeting even the basic needs of the nuclear family. The linguistic-related deficiency that results from such a situation is low access to, and experience in, the languages children are learning. On the other hand, the book has been slow in compensating for sociological and linguistic inadequacies in the system, both as a means of documentation and as a tool for socialisation and literacy development through literacy activities. Consequently, many growing Nigerians are linguistically "malnourished" in both local and the English languages, engendering poor proficiency in both.

However, the environment still provides opportunities for language learning, which can be exploited by the school, thus first compensating for inadequacies in the system, and then directing learners to crucial elements in their environments that can expand language experience through multimodal and multimedia teaching. Enabling children to bring their personal activities into the classroom and to take the class to their family and environment would lead to the development of autonomous learners capable of improving their English proficiency throughout their lifetime. 


\section{REFERENCES AND NOTES:}

Callow, J. (2008).Show me: Principles for assessing students' visual literacy. The reading teacher, 61, 616-626.

Christopher, Nkechi M. (2008). Social and educational impact of language assessment in Nigeria.Nordic Journal of African Studies 17, 198-210.

Erlenawati, S. (2005).Language difficulties of international students in Australia: The effects of prior learning experience. International Education Journal, 6, 567-580.

Gardner, R. C. (1991). Attitudes and motivation in second language learning.In A. G. Reynolds, (Ed.), Bilingualism, multiculturalism, and second language learning: The McGill Conference in honour of Wallace E. Lambert (pp. 43-63). Hillsdale, N.J.: Lawrence Erlbaum Associates.

Gardner, R. C. (1983). Learning another language: A true social psychological experiment.Journal of language and social psychology, 2, 219-239.

Gardner, R. C., Masgoret, A. \& Tremblay, P. F. (1999).Home background characteristics and second language learning.Journal of language and social psychology, 18, 419437.

Hamers, J. F. \& Blanc, M. H. A. (2000).Bilinguality and bilingualism, Cambridge: Cambridge University Press.

Jarovinskij, A. (1995). On bilingual socialization.In K. E. Nelson \& Z. Réger (Eds.) Children's Language (Vol. 8, pp. 23-40). Hillsdale N.J.: Lawrence Erlbaum Associates.

LaMonde, A. \& Rogers, T. (2007). Infusing arts/multimedia into a secondary pre-service course on language and literacy across the disciplines as imaginative and critical practices.Language \& Literacy, 9, 1-28.

Nokes, J. D. (2008). The observation/ inference chart: improving students' abilities to make inferences while reading non-traditional texts. Journal of adolescent and adult literacy, 51, 538-546.

Savignon, S. J. (1987). Communicative language teaching.Theory into Practice: Teaching Foreign Languages, 26, 235-242.

Silver-Pacuilla, H. (2006). Access and benefits: Assistive technology in adult literacy.Journal of adolescent and adult literacy, 50, 114-125.

Thompson, M. (2008). Multimodal teaching and learning: Creating spaces for content teachers. Journal of adolescent and adult literacy, 52, 144-153.

Weinstein, S. (2006). A love for the thing: The pleasures of rap as a literate practice. Journal of adolescent and adult literacy, 50, 270-281.

MISPLACED -Nicholls, J. \& Wells, G. (1985). Editors' Introduction. In G. Wells \& J. Nicholls (Eds.), Language and Learning: An Interactional Perspective (pp. 1-19). London: Falmer Press.

Wilson, A. A. (2008). Moving beyond the page in content area literacy: comprehension instruction for multimodal texts in science.The Reading Teacher, 62, 153-156.

Zhongganggao, C. (2001).Second language learning and the teaching of grammar. Education, 122, 326-337. 


\section{SUMMARY}

\section{Contextual Factors, Bilingualism and English Language Learning among a Group of Primary School Pupils in Nigeria}

\section{Nkechi M. Christopher}

University of Ibadan, Nigeria.

Contextual factors impinge directly and indirectly on second language learning through its influence on attitudes towards, and motivation to learn, a language among learners of a target language. This paper describes language learning situation, bilingual behaviour and academic performance of some primary school pupils. It suggests that learners' independent use of digital and literacy activities could be harnessed for multimodal teaching where digital learning facilities have not been provided by the school. The researcher believes that such inclusion would encourage autonomous and collaborative learning among students; empowering learners to take responsibility for their own language learning - an attitude toward learning that would enable them overcome low Englishproficiency levels in the larger society.

Keywords: bilingualism/bilinguality, environment, language, multimedia 